\title{
Prevalence of malaria and related haemosporidian parasites in two shorebird species with different winter habitat distribution
}

\author{
Elizabeth Yohannes • Asta Križanauskienè • \\ Mihai Valcu $\cdot$ Staffan Bensch $\cdot$ Bart Kempenaers
}

Received: 23 August 2008/Revised: 25 September 2008/Accepted: 7 October 2008/Published online: 11 November 2008

(C) The Author(s) 2008. This article is published with open access at Springerlink.com

\begin{abstract}
Parasites can have strong effects on host life-history and behaviour, and result in changes in host population dynamics and community structure. We applied a PCR-based technique and examined prevalence of malaria and related haemosporidian parasites in two arctic breeding shorebird species: the Semipalmated Sandpiper (Calidris pusilla) and the Pectoral Sandpiper (C. melanotos). During the non-breeding season, Semipalmated Sandpipers inhabit coastal marine habitats, whereas Pectoral Sandpipers are found in inland areas. In accordance with the hypothesis that the risk of parasite infection is higher in a species wintering in freshwater areas, we found Plasmodium sp. infection during the breeding season only in Pectoral Sandpipers, whereas Semipalmated Sandpipers were parasite free. However, even in Pectoral Sandpipers sampled in the arctic, prevalence of malaria parasites was very low $(<3 \%$ of individuals, $n=114)$. Overall, three different Plasmodium sp. lineages were found, one of which has never been described before.
\end{abstract}

Communicated by F. Bairlein.

E. Yohannes $(\bowtie) \cdot$ M. Valcu $\cdot$ B. Kempenaers

Behavioural Ecology and Evolutionary Genetics,

Max Planck Institute for Ornithology,

P.O. Box 1564, 82305 Starnberg (Seewiesen),

Germany

e-mail: yohannes@orn.mpg.de

\section{A. Križanauskienè}

Institute of Ecology, Vilnius University,

Akademijos 2, 08412 Vilnius, Lithuania

S. Bensch

Department of Ecology, Lund University,

Ecology Building, 22362 Lund, Sweden
Keywords Avian malaria - Haemosporidian parasites . Shorebirds

\section{Introduction}

Seasonal movement of the host from parasite-rich to parasite-free habitats, or the other way round, is expected to shift the co-evolutionary dynamics in host-parasite relationships (Gomulkiewicz et al. 2000; Forde et al. 2004, Morgan et al. 2005). One of the partners (host or parasite) that is either pre-adapted to the new environment or is more flexible for faster adaptation to novel conditions is expected to have the upper hand in the arms race. Hence, the general host-parasite interactions may be directly affected by species range distributions and migration patterns.

Often, natural populations of hosts and parasites are spatially separated at least during part of the year, so that some areas of a host's range are parasite-poor. Some longdistance migratory species, such as high-arctic breeding shorebirds, appear to avoid parasite-prone areas (e.g. freshwater inland habitats) but instead rely strictly (yearround) on haemosporidian parasite-poor habitats such as high arctic tundra, coastal sand beaches, mudflats and lagoons, and saltwater marshes. Yet, breeding and overwintering in these habitats require energetically and time-demanding migratory journeys and living in often harsh environmental conditions. Thus, physiological tradeoffs between immunological investment and energetically costly life history-traits related to long-distance migration (e.g. fattening, sustained flight) and breeding in climatically adverse conditions (thermoregulation, fast chick growth) were proposed as possible driving factors behind the use of specific habitat types by migrating shorebirds (Piersma 1997, 2003). 
Based on the dichotomy of habitat distribution observed in migrating shorebirds, it has been suggested that habitat selection might be related to the different habitat-related disease-risks (e.g. Piersma 2003). The idea is supported by a study that examined the prevalence of avian malaria infection in 31 shorebird species sampled in the arctic, in Europe and in marine and inland West Africa (Mendes et al. 2005). This study showed significantly higher prevalence of malaria parasites in species that rely on freshwater inland habitats (mostly tropical wetlands) than in species that occur in marine habitats $(9.6 \%$ of a total of 501 vs $0.7 \%$ of 816 individuals screened).

We applied a PCR-based technique and examined the prevalence of avian haemosporidian infections in two shorebird (Calidris) species that breed sympatrically in the high arctic, but differ in habitat choice during the nonbreeding season (Fig. 1). The Semipalmated Sandpiper (Calidris pusilla) migrates to South America through the prairies. The northward migration from the wintering ground is believed to be along the Atlantic coast (mainly for the eastern breeding population) and through interior North America. The species winters along northern and central coasts of South America and relies mainly on shallow lagoons, low tidal zones and coastal marine habitats. The Pectoral Sandpiper (C. melanotos) is usually found in freshwater habitats and migrates across mid-continental North America (Fig. 1). Its main wintering area is spread across the interior of mid-continental South America and consists primarily of wet marshlands and grassy areas, usually far from tidal areas and occasionally higher into alpine puna zone (for details on migration, distribution and habitat, see: de Hoyo et al. 1996; Holmes and Pitelka 1998;
Myers and Myers 1979; Parker et al. 1982; Stotz et al. 1996).

Thus, based on potential exposure to vectors, we predicted relatively higher prevalence of malaria parasites in Pectoral Sandpipers compared to Semipalmated Sandpipers. Semipalmated Sandpipers have not been investigated for blood parasites, whereas Mendes et al. (2005) reported the absence of malaria parasites (Plasmodium sp.) in a single Pectoral Sandpiper caught along the East Atlantic Flyway.

\section{Materials and methods}

The study was conducted near Barrow, Alaska, $\left(71^{\circ} 18^{\prime} \mathrm{N}\right.$, $156^{\circ} 44^{\prime} \mathrm{W}$ ) the northern tip of the Arctic Coastal Plain (for details of the study site, see Ashkenazie and Safriel 1979). Both species arrived on the breeding grounds between the end of May and the beginning of June. Semipalmated Sandpipers were studied between 5 June and 13 July 2004 and between 9 June and 10 July 2005. Pectoral Sandpipers were studied between 26 May and 4 July 2006.

Male and female Semipalmated Sandpipers were caught using walk-in traps during incubation. Incubating female Pectoral Sandpipers were caught on the nest using spring traps. Male Pectoral Sandpipers were caught using mistnets. Each bird was banded with a unique combination of colour bands and an aluminum US Fish and Wildlife Service band.

Genomic DNA was extracted from bird blood samples stored in Queens's Lysis buffer (0.01 M Tris-HCl, 0.01 M $\mathrm{NaCl}, 0.01 \mathrm{M}$ EDTA, $1 \% n$-Lauroylsarcosine, $\mathrm{pH} 8.0$; Seutin et al. 1991) using the GFX Genomic Blood DNA
Fig. 1 The breeding, migration and wintering distribution range of the Pectoral Sandpiper (Calidris melanotos) and the Semipalmated Sandpiper (C. pusilla). The intensity of the green colour within each migration range reflects relative densities of individuals observed at stop-over sites (pale green correspond to low densities; see "Materials and methods" for details)

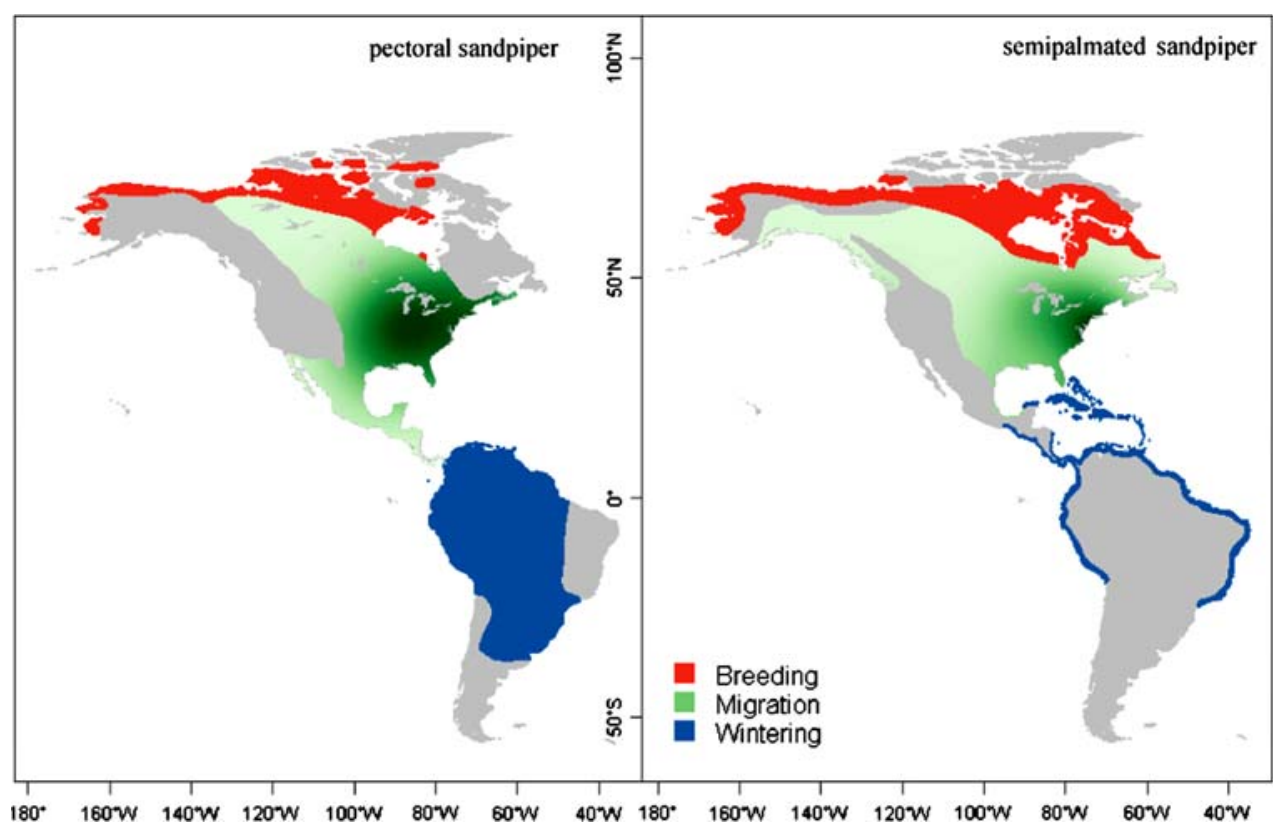


Purification Kit (GE Healthcare Europe, Freiburg, Germany).

Samples from 114 Pectoral Sandpipers (20 males and 94 females) and 84 Semipalmated Sandpipers (23 males and 25 females in 2004, and 16 males and 20 females in 2005) were screened for parasites using a nested PCR protocol (primer pair 1: HAEMNFI and HAEMNR3 for Haemoproteus, Plasmodium and Leucocytozoon; primer pair 2a: HAEMF and HAEMR2 for Haemoproteus and Plasmodium; primer pair 2b: HAEMFL and HAEMR2L for Leucocytozoon) targeting a 479-bp fragment (excluding primers) of the parasite cytochrome $b$ gene (Hellgren et al. 2004). Direct sequencing of positive reactions was performed using the HAEMF primer and these were loaded on an ABI PRISM 3100 sequencing robot (Applied Biosystems). This procedure also permits precise identification of parasitic lineages when identical parasites occur in different avian host species (Hellgren et al. 2007a).

We compared the blood parasites detected in the sandpipers with blood parasites from our unpublished database (available on request from S. Bensch) using local BLAST search in BioEdit (Hall 1999). Lineages are defined by their cytochrome $b$ haplotype of the $479 \mathrm{bp}$ sequence between the primers HAEMF and HAEMR2. This database contains 216 unique Plasmodium lineages, 325 Haemoproteus lineages and 89 Leucocytozoon lineages.

Maps (Fig. 1) were generated with R 2.6.2 (R Development Core Team 2007) using species distribution ranges available in digital format from Nature Serve (Ridgely et al. 2007). Relative densities of individuals observed at stop-over sites (both in spring and autumn migration; indicated on the maps in green) were estimated using a gaussian smoothing kernel (Baddeley and Turner 2005) applied on individuals' resighting data (Pectoral Sandpiper, $n=1,558$, time span 1911-2008; Semipalmated Sandpiper, $n=9,067$, time span $=1932-2007$ ) from the Avian Knowledge Network (Cornell Laboratory of Ornithology, http://www.avianknowledge.net).

\section{Results and discussion}

We detected no infections by parasites from the genera Haemoproteus and Leucocytozoon in either of the species. Hence, these birds may not be exposed to parasites transmitted by biting midges, Hippoboscid flies or black flies (Valkiunas 2005). The 84 Semipalmated Sandpipers were also negative for Plasmodium parasites and hence completely free of haemosporidian parasites. Among the 114 Pectoral Sandpipers screened, 3 individuals $(2.6 \% ; 1$ male, 2 females) scored positive for Plasmodium infection. These represented three different Plasmodium lineages. In one individual (male), we detected a new lineage PESA01
(GenBank accession number EU684543), which was most similar to a Plasmodium lineage retrieved from a Brown Hawk Owl (Ninox scutulata) from Singapore (AY099035), Asia (Perkins and Schall 2002). A sequence closely matching PESA01 has been recorded in a White-tipped Dove (Leptotila verreauxi) (GenBank DQ241521) from Uruguay (Durrant et al. 2006). Two other individual Pectoral Sandpipers were screened positive for two different Plasmodium lineages each: BT7 (AY393793) and SW5 (AF495574). The lineage BT7 was first described for Bluethroats (Luscinia svecica) from Sweden (Hellgren 2005), but has also been detected in Great Tits (Parus major) and Blue Tits (Cyanistes caeruleus) from the UK (Wood et al. 2007), in Pacific Golden Plovers (Pluvialis fulva) from Hawaii (Beadell et al. 2006), in the Common Rosefinch (Carpodacus erythrinus) from Korea (Beadell et al. 2006), in the Red-flanked Bluetail (Tarsiger cyanurus) from Myanmar (Ishtiaq et al 2007), and in the Common Buzzard (Buteo buteo), the Rough-legged Buzzard (Buteo lagopus) and the Eurasian Sparrowhawk (Accipiter nisus) from Germany (Krone et al 2008). The SW5 lineage has previously been found in two migratory warbler species of the genera Acrocephalus: the Sedge Warbler (A. schoenobaenus) from Nigeria (Waldenström et al. 2002) and the Great Reed Wwarbler (A. arundinaceus) from Sweden (Bensch et al. 2007).

Overall, our results are consistent with previous studies in shorebirds, which showed very low prevalence of malaria parasites in shore birds (e.g. Peirce 1981; Earlé and Underhill 1993; Mendes et al. 2005). Earlier studies (that mainly applied blood smear techniques) also indicate the absence of blood parasites in the arctic. For instance, Williams (1978) reported the absence of blood parasites from Charadrii species sampled in northeastern Greenland. Likewise, Borg (1992) reported the absence of parasites from 298 individuals (11 species of Charadrii) on southward migration at Öland, Sweden. No blood parasites were found in five species of Charadriiformes breeding in the Asian arctic tundra near Lake Pronchishcheva $\left(75^{\circ} 16^{\prime} \mathrm{N}\right.$, $112^{\circ} 28^{\prime} \mathrm{E}$ ), northeastern Taimyr Peninsula, Russia (Earlé and Underhill 1993). Among 215 birds (65 marine/saline and 150 freshwater) examined using PCR-based assays, Mendes et al. (2005) found no avian malaria in the arctic.

According to Valkiūnas (2005), the scarcity of haematozoa in marine and coastal birds seems to be a general rule with a few exceptions. The observed absence of blood parasites in Semipalmated Sandpipers, a species that uses coastal marine habitats during migration, is in line with the hypothesis that this species is exposed to low levels of parasites by employing a marine/saline-dominated migration route (Piersma 1997, 2003; Figuerola 1999). Pectoral Sandpipers showed low levels of Plasmodium prevalence, supporting the idea that they run a relatively higher risk of 
infection by using more freshwater habitats during migration and overwintering.

The relative low parasite prevalence could be explained by the scarcity of parasite vectors across a large part of the distribution of the species, but also by additional factors such as the immunological fitness of the host and the absence of alternative hosts that could serve as a reservoir for the parasite (Cardona et al. 2002; Garvin and Remsen 1997). An optimal condition created by the interaction of such factors may account for inter- and intra-specific habitat, geographic and latitudinal variation in parasite prevalence (e.g. Tella et al. 1999).

With some notable exceptions (Beadell et al. 2006), little is known about the geographical distribution of lineages of avian blood parasites. The presence of the two previously recorded Plasmodium lineages (BT7 and SW5) in Pectoral Sandpipers emphasizes that some Plasmodium parasites may be globally distributed (occurring in tropical, temperate and arctic regions), with taxonomically very broad host distributions, infecting both passerines and shorebirds. Parasites transmitted during the winter that could not defeat or escape the immune system of individual birds might have been removed from the blood circulation before arrival at the tundra breeding grounds. In Blackcaps (Sylvia atricapilla), it has been shown that some Plasmodium and Haemoproteus parasites are present in the blood only in the winter (Pérez-Tris and Bensch 2005). However, the general pattern seems to be that tropical- and winter-transmitted parasites are also present in the blood when birds are at northern breeding latitudes (Hellgren et al. 2007b). Hence, the absence of parasites observed in Semipalmated Sandpipers and the very low prevalence in Pectoral Sandpipers at their breeding grounds do suggest that winter prevalence might also be low. In shorebirds, Mendes et al. (2005) reported that infection rates at the wintering grounds can be much higher than we found in the arctic breeding grounds. Hence, with data only from the breeding season we cannot completely rule out that wintering in freshwater habitats might lead to higher infection rates. This should be tested by sampling shorebirds at the wintering grounds.

\section{Zusammenfassung}

Vorkommen von Malaria- und Haemosporidia-Parasiten bei zwei Standläuferarten mit unterschiedlichen Überwinterungshabitaten

Mit Hilfe von PCR-basierten Methoden wurde das Vorkommen von Malariaparasiten bei zwei arktischen Strandläufern untersucht, beim Sandstrandläufer (Calidris pusilla) und beim Graubruststrandläufer (C. melanotos). Außerhalb der Brutzeit nutzen Sandstrandläufer marine
Küstenhabitate, während Graubruststrandläufer in inländischen Feuchtgebieten zu finden sind. In Übereinstimmung mit der Hypothese, dass das Infektionsrisiko in Süßwasser-Feuchtgebieten größer ist, wurden am arktischen Brutplatz Plasmodium-Infektionen nur bei Graubruststrandläufern festgestellt, während kein einziger Sandstrandläufer infiziert war. Allerdings war selbst bei Graubruststrandläufern der Anteil an infizierten Individuen sehr gering $(<3 \%$ der Individuen, $n=114)$. Wir fanden drei verschiedene Plasmodium-Linien, von denen eine nie zuvor beschrieben wurde.

Acknowledgments We are grateful to Rick Lanctot from the USFWS in Anchorage and Glenn Sheehan from the Barrow Arctic Science Consortium in Barrow for logistical support, and Richard E. Johnson and Holger Schielzeth for valuable comments. The study was supported financially by the Max Planck Society, the Swedish Research Council (VR) and the Swedish Research Council for Environment, Agricultural Sciences and Spatial Planning (FORMAS). The study was conducted under a permit of the US Fish and Wildlife Service.

Open Access This article is distributed under the terms of the Creative Commons Attribution Noncommercial License which permits any noncommercial use, distribution, and reproduction in any medium, provided the original author(s) and source are credited.

\section{References}

Ashkenazie S, Safriel UN (1979) Breeding cycle and behavior of the semipalmated sandpiper at Barrow, Alaska. Auk 96:56-67

Baddeley A, Turner R (2005) Spatstat: an R package for analyzing spatial point patterns. J Stat Softw 12:1-42

Beadell JS, Ishtiaq F, Covas R, Melo M, Warren BH, Atkinson CT, Bensch S, Graves GR, Jhala YV, Peirce MA, Rahmani AR, Fonseca DM, Fleischer RC (2006) Global phylogeographic limits of Hawaii's avian malaria. Proc R Soc Lond B 273:2935-2944

Bensch S, Waldenström J, Jonzen N, Westerdahl H, Hansson B, Sejberg D, Hasselquist D (2007) Temporal dynamics and diversity of avian malaria parasites in a single host species. J Anim Ecol 76:112-122

Borg K (1992) Blood parasites and their modes of spread among birds. Ornis Svec 2:45-54

Cardona JC, Ihejirika A, McClellan L (2002) Haemoproteus lophortyx infection in bobwhite quail. Avian Dis 46:249-255

del Hoyo J, Elliott A, Sargatal J (eds) (1996) Handbook of birds of the world, vol 3. Hoatzin to Auks. Lynx, Barcelona

Durrant LK, Beadell SJ, Istiaq F, Graves RG, Olson LS, Gering E, Peirce AM, Milensky CM, Schmidt KB, Gebhard C, Fleischer RC (2006) Avian hematozoa in South America: a comparison of temperate and tropical zones. Ornithol Monogr 60:98-111

Earlé RA, Underhill LG (1993) Absence of haematozoa in some Charadriiformes breeding in the Taimyr Peninsula, Russia. Ardea 81:21-24

Figuerola J (1999) Effects of salinity on rates of infestation of waterbirds by haematozoa. Ecography 22:681-685

Forde SE, Thompson JN, Bohannan BJM (2004) Adaptation varies through space and time in a coevolving host-parasitoid interaction. Nature 431:841-844

Garvin MC, Remsen JV (1997) An alternative hypothesis for heavier parasite loads of brightly colored birds: exposure at the nest. Auk 114:179-191 
Gomulkiewicz R, Thompson JN, Holt RD, Nuismer SL, Hochberg ME (2000) Hot spots, cold spots, and the geographic mosaic theory of coevolution. Am Nat 156:156-174

Hall TA (1999) BioEdit: a user-friendly biological sequence alignment editor and analysis program for Windows 95/98/NT. ver. 6.0.6. Nucleic Acids Symp Ser, pp 95-98

Hellgren O (2005) The occurrence of haemosporidin parasites in the Fennoscandian bluethroat (Luscinia svecica) population. J Ornithol 146:55-60

Hellgren O, Waldenström J, Bensch S (2004) A new PCR assay for simultaneous studies of Leucocytozoon, Plasmodium and Haemoproteus from avian blood. J Parasitol 90:797-802

Hellgren O, Krizanauskiene A, Valkiunas G, Bensch S (2007a) Diversity and phylogeny of mitochondrial cytochrome $b$ lineages from six morphospecies of avian Haemoproteus Haemosporida Haemoproteidae. J Parasitol 93:889-896

Hellgren O, Waldenström J, Peréz-Tris J, Szöllősi E, Hasselquist D, Krizanauskiene A, Ottosson U, Bensch S (2007b) Detecting shifts of transmission areas in avian blood parasites-a phylogenetic approach. Mol Ecol 16:1281-1290

Holmes R, Pitelka FA (1998) Pectoral sandpiper (Calidris melanotus). In: Poole A, Gill F (eds) The birds of North America, no. 348. The Birds of North America, Philadelphia

Ishtiaq F, Gering E, Rappole JH, Rahmani AR, Jhala YV, Dove CJ, Melinsky C, Olson SL, Peirce MA, Fleischer RC (2007) Prevalence and diversity of avian hematozoan parasites in Asia: a regional survey. J Wildl Dis 43:382-398

Krone O, Waldenström J, Valkiūans G, Lessow O, Müller K, Lezhova TA, Fickel J, Bensch S (2008) Haemosporidian blood parasites (Haemosporida, Haemoproteidae) in European birds of prey and owls. J Parasitol 94:709-715

Mendes L, Piersma T, Lecoq M, Spaans B, Ricklefs RE (2005) Disease-limited distributions? Contrasts in the prevalence of avian malaria in shorebird species using marine and freshwater habitats. Oikos 109:396-404

Morgan AD, Gandon S, Buckling A (2005) The effect of migration on local adaptation in a coevolving host-parasite system. Nature 437:253-256

Myers JP, Myers LP (1979) Shorebirds of coastal Buenos Aires Province, Argentina. Ibis 121:186-200

Parker TAIII, Parker SA, Plenge MA (1982) An annotated checklist of Peruvian birds. Buteo Books, Vermillion
Perkins SL, Schall JJ (2002) A molecular phylogeny of malarial parasites recovered from cytochrome $\mathrm{b}$ gene sequences. J Parasitol 88:972-978

Peirce MA (1981) Distribution and host-parasite check-list of the haematozoa of birds in western Europe. J Nat Hist 15:419-458

Piersma T (1997) Do global patterns of habitat use and migration strategies co-evolve with relative investments in immunocompetence due to spatial variation in parasite pressure? Oikos 80:623-631

Piersma T (2003) "Coastal" versus "inland"shorebird species: interlinked fundamental dichotomies between their life- and demographic histories? Wader Study Group Bull 100:5

Pérez-Tris J, Bensch S (2005) Dispersal increases local transmission of avian malarial parasites. Ecol Lett 8:838-845

R Development Core Team (2007) R: a language and environment for statistical computing. R Foundation for Statistical Computing, Vienna, Austria. ISBN 3-900051-07-0. http://www.R-project.org

Ridgely RS, TF Allnutt T, Brooks DK, McNicol DW, Mehlman BE, Young, JR, Zook (2007) Digital distribution maps of the birds of the western hemisphere. Version 3.0. NatureServe, Arlington

Seutin G, White BN, Boag PT (1991) Preservation of avian blood and tissue samples for DNA analyses. Can J Zool 69:82-90

Stotz DF, Fitzpatrick JW, Parker TAIII, Moskovits DK (1996) Neotropical birds: ecology and conservation. University of Chicago Press, Chicago

Tella JL, Guillermo B, Foreros MG, Gajo AL, Dona'zar A (1999) Habitat, world geographic range and embryonic development of hosts explain the prevalence of avian hematozoa at small spatial and phylogenetic scales. Proc Natl Acad Sci USA 96:1785-1789

Valkiūnas G (2005) Avian malaria parasites and other haemosporidia, 1st edn. CRC Press, Boca Raton

Waldenström J, Bensch S, Kiboi S, Hasselquist D, Ottosson U (2002) Cross-species infection of blood parasites between resident and migratory songbirds in Africa. Mol Ecol 11:1545-1554

Williams AE (1978) Avian blood parasite studies. In: Green GH, Greenwood ND (eds) Joint biological expedition to north east Greenland 1974. Dundee University N.E. Greenland Expedition, Dundee

Wood MJ, Cosgrove C, Wilkin TA, Knowles SCL, Day KP, Sheldon BC (2007) Within-population variation in prevalence and lineage distribution of avian malaria in blue tits, Cyanistes caeruleus. Mol Ecol 16:3263-3273 